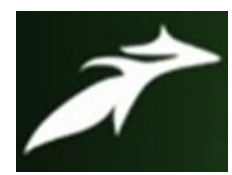

UDANGSHRI BRAHMA et al, International Journal of Advances in Agricultural Science and Technology, Vol.7 Issue.10, October-2020, pg. 34-39

\title{
ADOPTION LEVEL OF SERICULTURE FARMERS TOWARDS IMPROVED SERICULTURE PRODUCTION TECHNOLOGY IN UDALGURI BLOCK OF UDALGURI DISTRICT, ASSAM
}

\author{
UDANGSHRI BRAHMA ${ }^{1}$; DR. DIPAK KUMAR BOSE ${ }^{2}$; SHIVAM YADAV \\ MSc Scholar, Associate Professor, MSc Scholar \\ Department of Agricultural Extension \& Communication \\ Sam Higginbottom University of Agricultural Technology \& Sciences, Prayagraj (211007) \\ DOI: 10.47856/ijaast.2020.v07i10.007
}

\begin{abstract}
Sericulture, the production of raw silk by means of raising caterpillars. Sericulture is our important agro-based rural industry that helps our economy and generates higher income and employment. It is practiced in a wide range of agro-climatic regions like forests, hilly areas and plains. In fact, the recent technological advancements have made it possible to practice it on an intensive scale, mainly due to increased profits obtained from it as compared to most of the crops and enterprises. Sericulture has a special place among the agro-based cottage industry of our country. The government of India initiated various programmes to promote sericulture in the country, following which sericulture took a rapid slide towards progress, emerging as one of the most economically viable, small scale agro-based industries. Hence the present study was undertaken to find out the adoption level of the sericulture farmers towards improved sericulture technology with respect to socio-economic profile of the farmers of Udalguri block of Udalguri district, Assam. The study revealed that most of the respondents (43.33\%) had medium level of Adoption followed by low (28.34\%) and high (28.33\%).
\end{abstract}

KEYWORDS- Sericulture, Adoption level, Socio-economic profile

\section{INTRODUCTION}

Sericulture in India has turned out to be a highly remunerative enterprise with minimum capital base and yielding reasonably good returns vis-a-vis other enterprises. Sericulture effectively transfers urban wealth to rural producers. It provides not only periodical return within a short period of time but also assure potential family employment opportunities around the year. A large chunk of labour is employed in all the sericulture activities and the industry is a boon to the labour-surplus countries like India. Sericulture also employs a sizable show of women labour. The women participation in sericulture ranges between 55 and 60 percent.

\section{HISTORY}

The ancient literature gives two views. According to one view, silk industry originated for the first time in India at the foot of the Himalayas, and from there it spread to the other countries of the world. Second view which has a great acceptance, says that this industry originated in China about 3000B.C. According to historians, now silk was exported from India to Rome during the reign of Kanishka in 58 B-C. Silk has a place of pride in the social and cultural lives of Indians, since it is superior to other textile fibers in qualities like durability, luster and low weight. Hence, it is regarded as the "queen of textiles"( $\mathrm{Li}, 2012)$.

\section{METHOD OF DATA COLLECTION}

Primary Data Collection: The primary data has been collected through survey and observation. Through schedule, data has been collected from the farmers of selected villages Schedule has been prepared with both close ended and open ended questionnaire. 


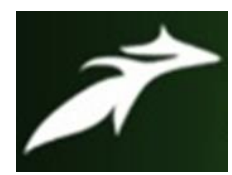

UDANGSHRI BRAHMA et al, International Journal of Advances in Agricultural Science and Technology, Vol.7 Issue.10, October-2020, pg. 34-39

ISSN: 2348-1358

Impact Factor: 6.057

NAAS Rating: 3.77

Secondary Data Collection: The secondary data has been collected through different source of materials, websites and other exiting records, various books, magazines, official records, research paper, internet, journals, news articles and other exiting sources of data.

\section{STATISTICAL ANALYSIS OF DATA}

Data collected were qualitative as well as quantitative. Qualitative data were converted into quantitative data. The quantitative data were tabulated on the basis of logical categorization method. Percentage, Coefficient correlation and Microsoft Excel were used for analysis purpose.

\section{RESULTS AND DISCUSSION}

Distribution of Socio-economic Profile Of the respondents

Table-1: Distribution of the respondents according to their Age.

\begin{tabular}{|l|l|l|l|}
\hline $\begin{array}{l}\text { S.I. } \\
\text { No. }\end{array}$ & \multicolumn{1}{|c|}{ Age (years) } & Frequency & Percentage \\
\hline $\mathbf{1}$ & Young (25-35 years) & 37 & 30.83 \\
\hline $\mathbf{2}$ & Middle age (36-55) & 57 & 47.5 \\
\hline $\mathbf{3}$ & Old (above 55) & 26 & 21.66 \\
\hline & Total & $\mathbf{1 2 0}$ & $\mathbf{1 0 0}$ \\
\hline
\end{tabular}

It is seen in the table 1 that 47.5 per cent of the respondents were of middle age group followed by middle age group 30.83 per cent and old age group 21.66 per cent respectively.

Table-2: Distribution of the respondents according to their Religion.

\begin{tabular}{|l|l|l|l|}
\hline $\begin{array}{l}\text { SI } \\
\text { no. }\end{array}$ & Particulates & Frequency & Percentage \\
\hline 1 & Hindu & 52 & 43.33 \\
\hline 2 & Christian & 68 & 56.66 \\
\hline & Total & 120 & 100 \\
\hline
\end{tabular}

The above table shows that 56.66 per cent respondents were Christian and 43.33 percent were Hindu and no other religion was found among them.

Table-3: Distribution of the respondents according to their Caste.

\begin{tabular}{|l|l|l|l|}
\hline $\begin{array}{l}\text { SI } \\
\text { no. }\end{array}$ & Particulates & Frequency & Percentage \\
\hline 1 & OBC & 45 & 37.5 \\
\hline 2 & ST & 75 & 62.5 \\
\hline & Total & 100 & 100 \\
\hline
\end{tabular}

The above table shows that 62.5 percent respondents were ST and 37.5 percent respondent were OBC caste was found among them

Table-4: Distribution of the respondents according to their Educational attainment.

\begin{tabular}{|l|l|l|l|}
\hline SI no. & Particulates & Frequency & Percentage \\
\hline 1 & Illiterate & 29 & 24.16 \\
\hline 2 & Primary school & 15 & 12.5 \\
\hline 3 & Secondary school & 16 & 13.33 \\
\hline 4 & High school & 17 & 14.16 \\
\hline 5 & Intermediate & 30 & 25 \\
\hline 6 & Graduation/PG & 13 & 10.83 \\
\hline & Total & 120 & 100 \\
\hline
\end{tabular}




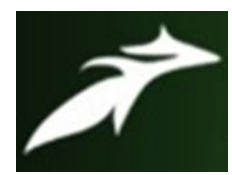

UDANGSHRI BRAHMA et al, International Journal of Advances in Agricultural Science and Technology, Vol.7 Issue.10, October-2020, pg. 34-39

ISSN: 2348-1358

Impact Factor: 6.057

NAAS Rating: 3.77

The above table shows that 25 percent respondents were Intermediate and 24.16 percent respondents were Illiterate and 14.16 percent respondents were High school and 13.33 percent respondents were secondary School and 12.5 percent respondents were Primary and 10.83 percent respondents were Graduation.

Table-5: Distribution of the respondents according to their Yearly income.

\begin{tabular}{|l|l|l|l|}
\hline $\begin{array}{l}\text { SI } \\
\text { no. }\end{array}$ & Particulates & Frequency & Percentage \\
\hline 1 & Income Rs.80000-160000 & 25 & 20.83 \\
\hline 2 & Income Rs.160001-240000 & 41 & 34.16 \\
\hline 3 & Income above Rs.240000 & 54 & 45 \\
\hline & Total & 120 & 100 \\
\hline
\end{tabular}

It is clear from the above table that 45 per cent respondents have Annual income Above Rs. 240000, 34.16per cent respondents have between Rs. 160001 - 240000, and 20.83 per cent respondents have income between Rs. 80000.-160000.

Table-6: Distribution of the respondents according to their Type of family.

\begin{tabular}{|l|l|l|l|}
\hline $\begin{array}{l}\text { SI } \\
\text { no. }\end{array}$ & Particulates & Frequency & Percentage \\
\hline 1 & Nuclear family & 73 & 60.83 \\
\hline 2 & Joint family & 47 & 39.17 \\
\hline & Total & 120 & 100 \\
\hline
\end{tabular}

The above table shows that 60.83 per cent respondents have nuclear family and other 39.17 per cent respondents have in joint family.

Table-7: Distribution of the respondents according to their Size of family.

\begin{tabular}{|l|l|l|l|}
\hline $\begin{array}{l}\text { SI } \\
\text { no. }\end{array}$ & Particulates & Frequency & Percentage \\
\hline 1 & Upto 5 members & 70 & 58.33 \\
\hline 2 & Above 5 members & 50 & 41.67 \\
\hline & Total & 120 & 100 \\
\hline
\end{tabular}

It is evident from the above table that 58.33 per cent of respondents had upto 5 members in the family whereas respondents 41.67 per cent respondents had Above 5 members in the family.

Table-8: Distribution of the respondents according to their Type of house.

\begin{tabular}{|l|l|l|l|}
\hline $\begin{array}{l}\text { SI } \\
\text { no. }\end{array}$ & Particulates & Frequency & Percentage \\
\hline 1 & Hut & 30 & 25.00 \\
\hline 2 & Semi-cemented & 43 & 35.83 \\
\hline 3 & Cemented & 47 & 39.17 \\
\hline & Total & 120 & $100 \%$ \\
\hline
\end{tabular}

The above table reveals that 39.17 per cent respondents live in cemented house followed by 35.83 per cent respondents live in Semi-cemented house and 25.00 per cent respondents live in hut type of house

Table-9: Distribution of the respondents according to their Land holdings.

\begin{tabular}{|l|l|l|l|}
\hline SI no. & Particulates & Frequency & Percentage \\
\hline 1 & Land size 2-3 acre. & 24 & 20.00 \\
\hline 2 & Land size 3.1- 4 acre. & 47 & 39.16 \\
\hline 3 & Land size above 4.1 acre. & 49 & 40.83 \\
\hline & Total & 120 & 100 \\
\hline
\end{tabular}




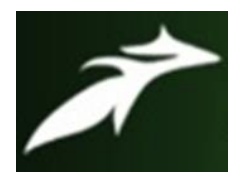

UDANGSHRI BRAHMA et al, International Journal of Advances in Agricultural Science and Technology, Vol.7 Issue.10, October-2020, pg. 34-39

ISSN: 2348-1358

Impact Factor: 6.057

NAAS Rating: 3.77

It is evident from the above table that 40.83 per cent respondents were having above 4.1 acre of land, 39.16 per cent respondents were having 3.1-4 acre of land and 20 per cent were having 2-3 acre of land.

Table-10: Distribution of the respondents according to their Extension contacts.

\begin{tabular}{|l|l|l|l|}
\hline $\begin{array}{l}\text { SI } \\
\text { no. }\end{array}$ & Particulates & Frequency & Percentage \\
\hline 1 & Low & 20 & 16.66 \\
\hline 2 & Medium & 68 & 56.67 \\
\hline 3 & High & 32 & 26.67 \\
\hline & Total & 120 & 100 \\
\hline
\end{tabular}

The data in the above table shows that most of the respondent $(56.67 \%)$ were found in medium extension contacts category followed by high category $(26.67 \%)$ and low (16.66\%) extension contacts category respectively.

ADOPTION LEVEL

Table-11: Distribution of the respondents according to their Adoption level

\begin{tabular}{|c|c|c|c|}
\hline \multirow[t]{2}{*}{ Technology } & \multicolumn{3}{|l|}{ Adoption level } \\
\hline & $\begin{array}{l}\text { Fully Adopted } \\
\text { F. (\%) }\end{array}$ & $\begin{array}{l}\text { Partially Adopted } \\
\text { F. (\%) }\end{array}$ & $\begin{array}{l}\text { Not Adopted } \\
\text { F. }(\%)\end{array}$ \\
\hline Soil testing and reclamation & $\begin{array}{l}29 \\
(24.16)\end{array}$ & $\begin{array}{l}66 \\
(55)\end{array}$ & $\begin{array}{l}25 \\
(20.84)\end{array}$ \\
\hline Mulberry variety (MR2,V1 etc) & $\begin{array}{l}33 \\
(27.5)\end{array}$ & $\begin{array}{l}57 \\
(47.5)\end{array}$ & $\begin{array}{l}30 \\
(25)\end{array}$ \\
\hline Planting spacing $(3 \times 3,5+3 \times 2$ etc. $)$ & $\begin{array}{l}43 \\
(35.83)\end{array}$ & $\begin{array}{l}60 \\
(50.00)\end{array}$ & $\begin{array}{l}17 \\
(14.16)\end{array}$ \\
\hline Drip irrigation & $\begin{array}{l}43 \\
(35.84)\end{array}$ & $\begin{array}{l}51 \\
(42.5)\end{array}$ & $\begin{array}{l}26 \\
(21.66)\end{array}$ \\
\hline FYM application & $\begin{array}{l}23 \\
(19.17)\end{array}$ & $\begin{array}{l}53 \\
(44.16)\end{array}$ & $\begin{array}{l}44 \\
(36.67)\end{array}$ \\
\hline Green manuring(Dhaincha,/Sunnhemp) & $\begin{array}{l}29 \\
(24.16)\end{array}$ & $\begin{array}{l}57 \\
(47.5)\end{array}$ & $\begin{array}{l}34 \\
(28.34)\end{array}$ \\
\hline $\begin{array}{l}\text { Biofertilizers } \\
\text { Azospirillum, Phosphobacteria }\end{array}$ & $\begin{array}{l}36 \\
(30.00)\end{array}$ & $\begin{array}{l}45 \\
(37.5)\end{array}$ & $\begin{array}{l}39 \\
(32.5)\end{array}$ \\
\hline Chemical fertilizer $(\mathrm{Kg}) \mathrm{N}: \mathrm{P}: \mathrm{K}$ & $\begin{array}{l}34 \\
(28.34)\end{array}$ & $\begin{array}{l}47 \\
(39.16)\end{array}$ & $\begin{array}{l}39 \\
(32.5)\end{array}$ \\
\hline IPM for Tukra disease & $\begin{array}{l}52 \\
43.34\end{array}$ & $\begin{array}{l}30 \\
(25.00)\end{array}$ & $\begin{array}{l}38 \\
(31.66)\end{array}$ \\
\hline IDM for Root rot disease & $\begin{array}{l}27 \\
(22.5)\end{array}$ & $\begin{array}{l}58 \\
(48.34)\end{array}$ & $\begin{array}{l}35 \\
(29.16)\end{array}$ \\
\hline $\begin{array}{l}\text { Silkworm race CSR } 2 \times 4 \text {, Double } \\
\text { hybrid etc., }\end{array}$ & $\begin{array}{l}25 \\
(20.83)\end{array}$ & $\begin{array}{l}67 \\
(55.83)\end{array}$ & $\begin{array}{l}28 \\
(23.34)\end{array}$ \\
\hline Rearing house & $\begin{array}{l}17 \\
(15.83)\end{array}$ & $\begin{array}{l}44 \\
(38.5)\end{array}$ & $\begin{array}{l}59 \\
(46.67)\end{array}$ \\
\hline
\end{tabular}




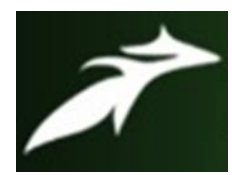

UDANGSHRI BRAHMA et al, International Journal of Advances in Agricultural Science and Technology, Vol.7 Issue.10, October-2020, pg. 34-39

ISSN: 2348-1358

Impact Factor: 6.057

NAAS Rating: 3.77

\begin{tabular}{|c|c|c|c|}
\hline $\begin{array}{l}\text { Shoot rearing } \\
\text { (entire mulberry shoot) }\end{array}$ & $\begin{array}{l}37 \\
(30.83)\end{array}$ & $\begin{array}{l}49 \\
(40.83)\end{array}$ & $\begin{array}{l}34 \\
(28.34)\end{array}$ \\
\hline Room disinfection & $\begin{array}{l}38 \\
(31.66)\end{array}$ & $\begin{array}{l}42 \\
(35)\end{array}$ & $\begin{array}{l}40 \\
(33.34)\end{array}$ \\
\hline Bed disinfection & $\begin{array}{l}36 \\
(30.00)\end{array}$ & $\begin{array}{l}50 \\
(41.67)\end{array}$ & $\begin{array}{l}34 \\
(28.33)\end{array}$ \\
\hline Hygiene maintenance & $\begin{array}{l}40 \\
(33.34)\end{array}$ & $\begin{array}{l}48 \\
(40)\end{array}$ & $\begin{array}{l}32 \\
(26.66)\end{array}$ \\
\hline Bed spacing & $\begin{array}{l}37 \\
(30.83)\end{array}$ & $\begin{array}{l}59 \\
(49.17)\end{array}$ & $\begin{array}{l}24 \\
(20)\end{array}$ \\
\hline Bed cleaning & $\begin{array}{l}41 \\
(34.16)\end{array}$ & $\begin{array}{l}62 \\
(51.67)\end{array}$ & $\begin{array}{l}17 \\
(14.17)\end{array}$ \\
\hline $\begin{array}{l}\text { Temperature and humidity } \\
\text { maintenance }\end{array}$ & $\begin{array}{l}30 \\
(25)\end{array}$ & $\begin{array}{l}70 \\
(58.33)\end{array}$ & $\begin{array}{l}20 \\
(16.67)\end{array}$ \\
\hline
\end{tabular}

Table-12: Distribution of respondents according to their overall Adoption level:

\begin{tabular}{|l|l|l|l|}
\hline S.N. & Adoption level & Frequency & Percentage \\
\hline $\mathbf{1}$ & Low(25-33) & 34 & 28.34 \\
\hline $\mathbf{2}$ & Medium(34-42) & 52 & 43.33 \\
\hline $\mathbf{3}$ & High(43-51) & 34 & 28.33 \\
\hline $\mathbf{4}$ & Total & 120 & 100.00 \\
\hline
\end{tabular}

The data in the above table showed that most of the respondents 43.33 per cent have medium adoption level followed by 28.34 per cent of respondents belonged to low Adoption level and 28.33 per cent fell in high adoption level.

Table-13: Relationship between socio-economic Characteristics and adoption level of sericulture farmers:

\begin{tabular}{|l|l|l|}
\hline Sl.No. & Characteristics & "r” value \\
\hline $\mathbf{1 .}$ & Age & $0.163 \mathrm{NS}$ \\
\hline $\mathbf{2 .}$ & Education & $0.295^{*}$ \\
\hline $\mathbf{3}$ & Occupation & $0.354^{*}$ \\
\hline $\mathbf{4}$ & Family size & $0.654^{*}$ \\
\hline $\mathbf{5}$ & Land holding & $0.035 \mathrm{NS}$ \\
\hline $\mathbf{6}$ & Annul income & $0.062 \mathrm{NS}$ \\
\hline $\mathbf{7}$ & Participation in Extension activities & $0.321^{*}$ \\
\hline
\end{tabular}

$*=$ Significant at $\mathrm{p}=0.05, \mathrm{NS}=$ Non Significant

The data from the above table shows that Education, Occupation, Family size and Extension activities are positively significant at $0.05 \%$ whereas Age, Land holdings and Annual income are positive but non-significant at $0.05 \%$ to extend of adoption of the respondent respectively. 


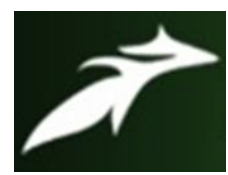

UDANGSHRI BRAHMA et al, International Journal of Advances in Agricultural Science and Technology, Vol.7 Issue.10, October-2020, pg. 34-39

\section{CONCLUSION}

It can be concluded that most of the respondents (43.33\%) had medium level of Adoption followed by low (28.34\%) and high (28.33\%) and the relationship between adoption level and socio- economic profile of respondents shows that Education $\left(0.295^{*}\right)$, Occupation $(0.354)$, Family size $\left(0.654^{*}\right)$ and Extension activities $(0.321 *)$ are positively significant at $0.05 \%$ whereas Age $(0.163 \mathrm{NS})$, Land holdings $(0.035 \mathrm{NS})$ and Annual income(0.062NS) are positive but non-significant at $0.05 \%$ to extend of adoption of the respondent respectively. Hence it is imperative that government and the experts should take more steps like training, field demonstration, more interaction with the farmers, more government schemes, loans so that more people can adopt sericulture as it also generates lots of employment which will help in the upliftment of society.

\section{REFERENCES}

[1]. Annual Report of Sericulture 2017. Central silk Board, Ministry of Textiles, Govt. of India, Bangaluru. P 1-2.

[2]. Anitha, R. 2011. Indian silk industry in the global scenario. International Journal of Multidisciplinary Management Studies, 1, 100-110.

[3]. Department of Sericulture, 2017 Chhattisgarh, Raipur. Detail report.

[4]. G.Savithri, P.Sujathamma and P.Neeraja 2013. Indian sericulture industry for sustainable rural economy. Int.jou.of Economics, commerce and research. Vol 3, Issue 2, 73-78pp.

[5]. Li, G., Liu, H., Li, T., Wang, J. 2012. Surface modification and functionalization of silk fibroin fibers/fabric toward high performance applications. Mater. Sci. Eng. C. 32 (2012) 627-636.

[6]. Prabha Sekhar and Ravikumar, C. 1991. Role of rural women in Indian sericulture, Proceedings of the International Congress on Tropical Sericulture Practices, 0p.cit. pp 65-71.

[7]. Roy, P., \& Sarkar, R. 2015. Work participation and income generation from sericulture: A case.

[8]. Santosh Kumar Dewangan 2018. Economics of Sericulture - A Study of Raigarh DistrictChhattisgarh International Journal for Research in Applied Science \& Engineering Technology (IJRASET) ISSN: 2321-9653; IC Value: 45.98; SJ Impact Factor: 6.887 Volume 6 Issue I. 